\title{
Transatlantica
}

Revue d'études américaines. American Studies Journal

Line Breaks in America: the Odds and Ends of Poetry

\section{THE LINE BENDS: Non-literal non-linear?}

Johanna Drucker

\section{(2) OpenEdition}

Journals

Electronic version

URL: https://journals.openedition.org/transatlantica/17358

DOI: 10.4000/transatlantica. 17358

ISSN: $1765-2766$

\section{Publisher}

Association française d'Etudes Américaines (AFEA)

\section{Electronic reference}

Johanna Drucker, "THE LINE BENDS: Non-literal non-linear?", Transatlantica [Online], 1 | 2021, Online since 01 July 2021, connection on 12 February 2023. URL: http://journals.openedition.org/ transatlantica/17358; DOI: https://doi.org/10.4000/transatlantica.17358

This text was automatically generated on 12 February 2023.

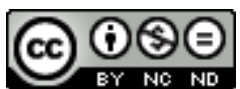

Creative Commons - Attribution-NonCommercial-NoDerivatives 4.0 International - CC BY-NC-ND 4.0 https://creativecommons.org/licenses/by-nc-nd/4.0/ 


\section{THE LINE BENDS: Non-literal non- linear?}

Johanna Drucker

\section{AUTHOR'S NOTE}

Johanna Drucker is an artist, writer, and academic known for her work in the areas of artist's books, visual forms of knowledge production, experimental typography, and digital humanities. She is currently the Breslauer Professor of Bibliographical Studies and Distinguished Professor in the Department of Information Studies at UCLA.

What if

What if the line doesn't break

What if the line doesn't break but $b$

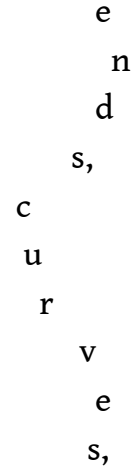

returns

on itself

so that the words pile back,

literally, upon each other

and then merge their referential planes with their expression?

Literary renderings reduce the possibility of semantic meaning.

Poetic distillation frees language from strict syntax. 
The break

Was always also visual, optical, graphically scored

Though

Breath seemed

In the gap and space it takes

to take

Under.

And if the line doesn't break but bends, curves, returns on itself so that the words pile back, literally, upon each other and then merge their referential planes with their expression-who can tell the difference in the pile-up between the first word and the last?

(See below: so you note, the position as well as the statement is an instruction for reading.)

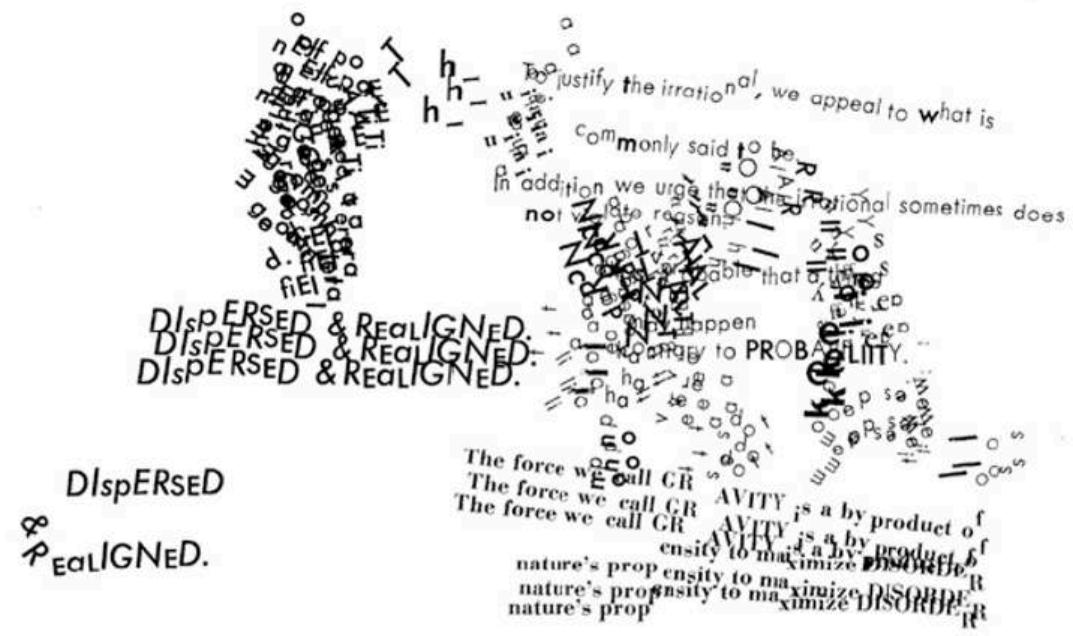

If sequence matters a little in the performance of syntax then how does the disruption of the graphical score alter the meaning machines that grind sense from the pace of one thing after another? Or not? We follow the resonance of language in our reading, not just the mechanics, and a bend, curve, return from a line above produces the very harmonics of poetry, thinking itself. My intention is to warp the sentence, pressure the paragraph, entangle the language so that it leaps across the quantum spaces of communication expression. Density to the point of implosion approaches one limit only to advance to another, spatially, dimensionally. No advantage to be gained except momentum and the excitement of the leap. A line that does not break bends and loops back so that the pile doesn't merge its referential matters but only disrupts meaning for our reading from above, thinking.

While writing this article about line breaks, I have a dream in which I am asking a male colleague to please give me a poem, a poem that really performs poetically, spatially, I am having great difficulty explaining to him that what I mean is that I want him to provide an example of spatial resonance-the capacity of words to reactivate each other across lines and stanzas, to anticipate and then recapitulate, shift meaning and 
value, not state it, but generate it. He is stumped by my questions and I feel I am not making myself clear. I mean

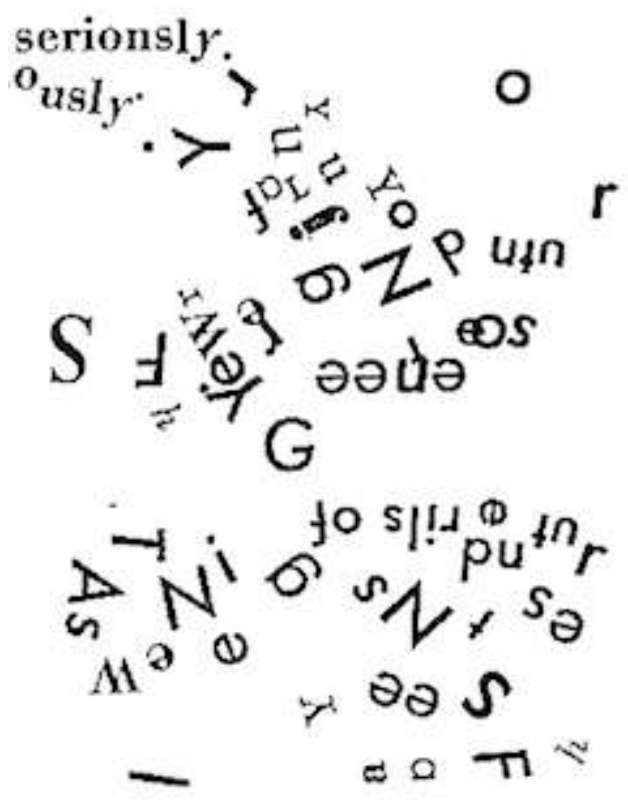

The linearity of reductive poetry is no worse than that of instrumental prose, but our expectations are different. How can I remind you of the words in the first line without drawing a circle around them?

When I was a typesetter in the mid-1970s and we were using first generation Compugraphic equipment, we had machines with no memory. A 37 character LED display was the only place in which to catch errors. The manuscript being copied sat directly in front of you, propped where today's screens would be, occupying the visual field. The LED display was to the right. Often poets were deeply disappointed by the way the carefully configured manuscript arrangements of their words, rendered with typewriters whose non-variable spacing was a feature of their design, looked in a typeface that had variable spacing. They wanted alignments preserved throughout. We were always explaining the technical obstacle to meeting their demands. The lines broke differently. Sometimes that seemed to break the poem.

Remind me, remind us, what happened before

Already

Above

Up we look and

The direction of recollection is retrospective

Reading races

Back and forth-or

Always forward-not. Always.

process is a random fleld, whose region of doma in space a random fu

ction whose

process is a random fleld, whose regionge of continuous $\mathrm{C}^{\mathrm{i}}$ changing values. 
I said, very few instances of visual poetry are all that interesting, but every poem is interesting

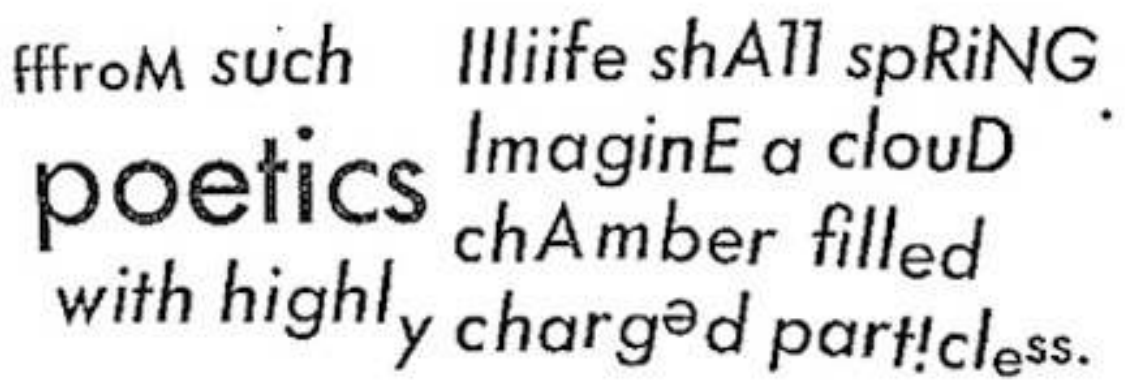

with regard to its usual form

When the line breaks, the poem will fall, and down will come something

and all.

AUTHOR

JOHANNA DRUCKER

UCLA 